\title{
Flora do Espírito Santo: clado de Merianthera e gêneros afins (Melastomataceae)
}

\author{
Flora of Espírito Santo: clade Merianthera and related genera (Melastomataceae)
}

\author{
Thuane Bochorny ${ }^{1,3}$ \& Renato Goldenberg ${ }^{2}$
}

\begin{abstract}
Resumo
Melastomataceae possui 22 gêneros e 182 espécies no Espírito Santo. Neste trabalho, são apresentados os tratamentos taxonômicos dos cinco gêneros pertencentes ao clado de Merianthera e gêneros afins, com 14 espécies: Behuria (3 espécies), Cambessedesia (2), Dolichoura (2), Huberia (2) e Merianthera (5). Também é apresentada uma chave de identificação para todas espécies ocorrentes no Espírito Santo, além de mapas e prancha com fotos.
\end{abstract}

Palavras-chave: angiospermas, flora, Mata Atlântica, taxonomia.

\begin{abstract}
Melastomataceae has 22 genera and 182 species in the state of Espírito Santo. In this work, we present a monograph for the five genera that belong to the clade Merianthera and related genera, with 14 species: Behuria (3 species), Cambessedesia (2), Dolichoura (2), Huberia (2) and Merianthera (5). We also present an identification key for all the species in the clade occurring in Espírito Santo, maps and photos.
\end{abstract}

Key words: angiosperms, flora, Mata Atlântica, taxonomy.

\section{Introdução}

A família Melastomataceae possui 22 gêneros e 182 espécies no Espírito Santo (Goldenberg, observação pessoal; BFG 2015), ocorrentes em praticamente todo o estado. Estas espécies vêm sendo objeto de estudo há 18 anos, e sobre elas foram produzidos dois artigos com flórulas regionais (Goldenberg \& Reginato 2006; Meirelles \& Goldenberg 2012) e vários artigos recentes referentes a espécies novas (Bacci \& Goldenberg 2015; Bacci et al. 2016a; Goldenberg \& Kohllmann 2016; Iglesias et al. 2016; Meyer et al. 2016). Apenas um tratamento para a Flora do Espírito Santo foi preparado para Miconia Ruiz \& Pav. (Bacci et al. 2016b).

$\mathrm{O}$ clado de Merianthera e gêneros afins ainda não possui designação formal de tribo e é um grupo com boa sustentação, composto pelos gêneros Behuria Cham., Cambessedesia DC., Dolichoura Brade, Huberia DC. e Merianthera Kuhlm. (Goldenberg et al. 2012b). Não há uma característica morfológica que possa ser considerada como sinapomórfica para o grupo, mas são plantas de porte geralmente pequeno, com estames desprovidos de conectivos prolongados abaixo das tecas, mas com apêndices, quando presentes, sempre dorsais. As plantas têm uma distribuição quase restrita a afloramentos rochosos e vegetação associada a estes afloramentos, em domínio de Mata Atlântica. Exceções são Cambessedesia, com diversidade concentrada em Campos Rupestres, ao longo da Cadeia do Espinhaço (Fidanza 2009), e Huberia, que também tem quatro espécies (de um total de 17), ocorrendo

\footnotetext{
Universidade Estadual de Campinas, Inst. Biologia, Prog. Pós-graduação em Biologia Vegetal, R. Monteiro Lobato 255, Cidade Universitária Zeferino Vaz, Barão Geraldo, 13083-862, Campinas, SP, Brasil.

${ }^{2}$ Universidade Federal do Paraná, Centro Politécnico, Depto. Botânica, Av. Cel. Francisco H. dos Santos s/n, Jardim das Américas, 80050-540, Curitiba, PR, Brasil.

${ }^{3}$ Autor para correspondência: tbochorny@gmail.com
} 
nos Andes peruanos e equatorianos (Baumgratz 2004). A opção por um tratamento taxonômico regional utilizando este clado como critério de inclusão já foi adotada por Justino et al. (2016).

O grupo é particularmente interessante no Espírito Santo. O estado é a única unidade geopolítica que abrange todos os gêneros do clado. Nove espécies, de um total de 14 ocorrentes no estado, são aparentemente endêmicas do mesmo. Um gênero biespecífico (Dolichoura) está restrito ao estado (Goldenberg \& Tavares 2007), assim como cinco das sete espécies de Merianthera (Goldenberg et al. 2012). Neste trabalho é apresentada uma monografia sobre as espécies do clado, que consta de chave de identificação, descrições, distribuição geográfica, prancha de fotos, relações de material examinado e comentários sobre as mesmas.

\section{Material e Métodos}

As exsicatas analisadas neste trabalho foram provenientes dos herbários, MBM, MBML, NY, RB, UEC, UPCB e VIES (siglas segundo Thiers, continuamente atualizado). As descrições dos gêneros foram baseadas apenas nas espécies ocorrentes no Espírito Santo, bem como as descrições das espécies, que foram baseadas em espécies coletados no estado. Por ter somente uma coleta para o Espírito Santo, Cambessedesia hilariana (Kunth) DC. teve sua descrição complementada com coletas de estados vizinhos, neste caso indicadas como "material adicional". As descrições de espécies dentro de um mesmo gênero foram feitas de forma paralela; as descrições de espécies de gêneros diferentes estão, na medida do possível, padronizadas, mas não exatamente paralelas. Para a descrição do cálice, não foram apresentadas medidas de tubo ou forma e dimensões das sépalas, quando este cálice era constituído por sépalas irregulares; o cálice apendiculado foi definido como aquele provido de um apêndice dorsal, em contraposição ao cálice inapendiculado, desprovido deste.

Para mais informações sobre os táxons tratados aqui, como listagens de sinonímias e tipos, ver Baumgratz (2004); Tavares (2005); Goldenberg \& Tavares (2007); Tavares et al. (2008); Fidanza (2009); Goldenberg \& Reginato (2009); Goldenberg et al. (2012) e Iglesias et al. (2016). Estes mesmos estudos foram consultados para informações sobre a distribuição geográfica (Fig. 1). Os dados sobre fenologia foram obtidos a partir de exemplares de herbário, e apenas aqueles coletados no Espírito Santo. Para dados sobre o ambiente físico e vegetação do Espírito Santo ver Garbin et al. (2017).
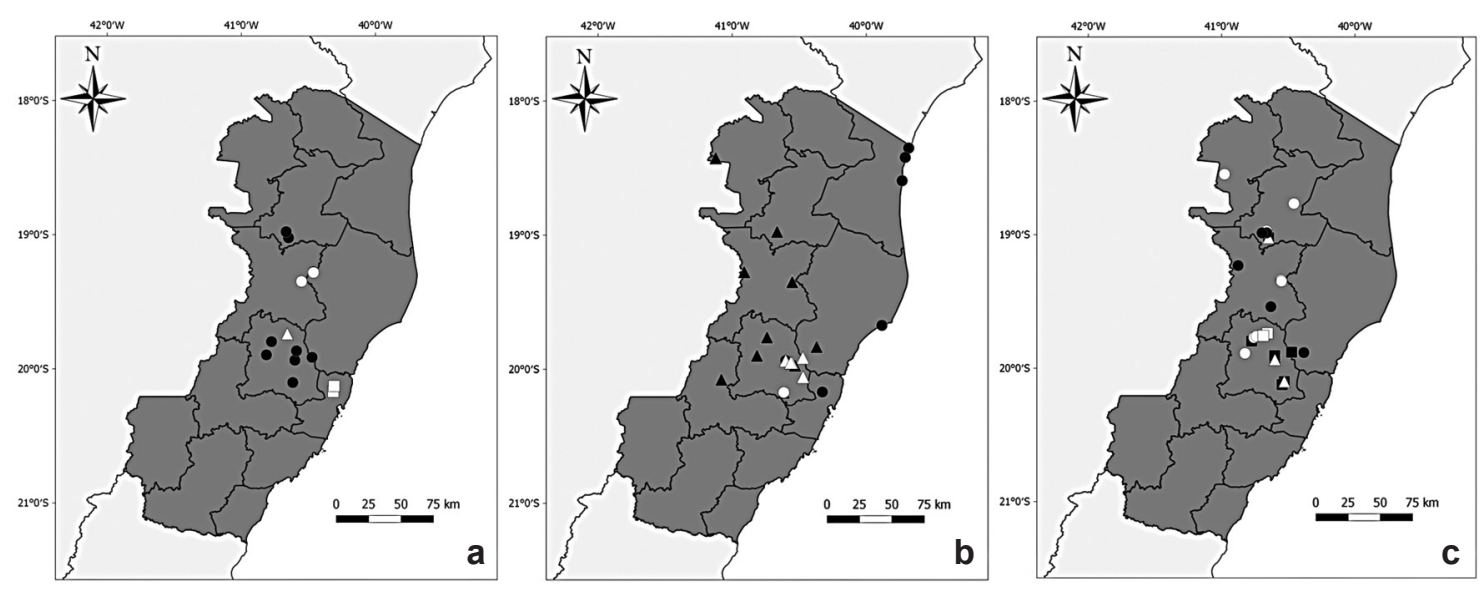

Figura 1 - a-c. Mapa de distribuição geográfica do clado de Merianthera e gêneros afins no Espírito Santo - a. $\Delta$ Behuria comosa; $\square$ Behuria mestrealvarensis; ○ Behuria capixaba; - Cambessedesia eichleri; b. ○ Dolichoura kollmannii; $\Delta$ Dolichoura spiritusanctensis; - Huberia ovalifolia; $\Delta$ Huberia espiritosantensis; c. - Merianthera bullata; $\Delta$ Merianthera burlemarxii; $\bigcirc$ Merianthera parvifolia; - Merianthera pulchra; Merianthera verrucosa.

Figure 1 - a-c. Distribution map of the clade Merianthera and related genera in Espírito Santo - a. $\Delta$ Behuria comosa; $\square$ Behuria mestrealvarensis; ○ Behuria capixaba; - Cambessedesia eichleri; b. ○ Dolichoura kollmannii; $\Delta$ Dolichoura spiritusanctensis; ○ Huberia ovalifolia; $\mathbf{\Delta}$ Huberia espiritosantensis; c. $\mathbf{\square}$ Merianthera bullata; $\Delta$ Merianthera burlemarxii; $\bigcirc$ Merianthera parvifolia; $\bullet$ Merianthera pulchra; Merianthera verrucosa. 


\section{Resultados e Discussão}

$\mathrm{O}$ clado de Merianthera e gêneros afins apresenta cinco gêneros no Espírito Santo, com um total de 14 espécies: Behuria (três spp.), Cambessedesia (duas spp.), Dolichoura (duas spp.), Huberia (duas spp.) e Merianthera (cinco spp.).

\section{Chave de identificação dos gêneros e espécies de Behuria, Cambessedesia, Dolichoura, Huberia e Merianthera no Espírito Santo}

1. Flores com pétalas amarelas ou vermelho-alaranjadas com base amarela; estames com conectivo inapendiculado (Cambessedesia)

2. Pecíolo com 4-5 mm de comprimento; lâmina 3-5,5 × 1-2,5 cm; ápice do ovário glabro

2'. Pecíolo com 2-3 mm de comprimento; lâmina 0,3-1,5 × 0,2-0,8 cm; ápice do ovário com tricomas glandulares

Cambessedesia hilariana

1'. Flores com pétalas brancas, rosadas, purpúreas ou roxas, nunca amarelas ou vermelho-alaranjadas; conectivo com apêndice(s) dorsal(is)

3. Estames fortemente dimórficos, com conectivo provido de dois apêndices, um ereto e outro descendente (Merianthera)

4. Ramos fistulosos; flores isoladas.

Merianthera burlemarxii

4'. Ramos não fistulosos; flores reunidas em inflorescências

5. Cálice com sépalas regulares

6. Hipanto levemente costado e liso; cálice inapendiculado........Merianthera bullata

6'. Hipanto nitidamente costado e verrucoso; cálice apendiculado

Merianthera verrucosa

5'. Cálice com sépalas irregulares

7. Pecíolo com 12-29 mm de comprimento; pedicelos com 10-16 $\mathrm{mm}$ de comprimento. Merianthera pulchra

7’. Folhas sésseis ou com pecíolos até $9 \mathrm{~mm}$ de comprimento; pedicelos com 3,5-6 mm de comprimento. Merianthera parvifolia

3'. Estames isomórficos, com conectivo provido apenas de um apêndice dorsal descendente

8. Flores 4-meras; fruto ruptídio (Huberia)

9. Sépalas oblongo-lineares, com 5,5-7 $\mathrm{mm}$ de comprimento ..Huberia espiritosantensis

9'. Sépalas largamente triangulares, com 1,5-2 mm de comprimento... Huberia ovalifolia

8'. Flores 5-7-meras; fruto velatídio

10. Pétalas brancas ou rosadas; estames com conectivo provido de apêndice reto ou levemente encurvado (Behuria)

11. Folhas com margens providas de tufos de tricomas nos espaços entre os dentes; flores em panículas. Behuria comosa

11'. Folhas com margens desprovidas de tufos de tricomas nos espaços entre os dentes; flores isoladas, em cimeiras ou dicásios

12. Pétalas com margens ciliadas e ápice do ovário com tricomas glandulares esparsos de 1,4-2,5 mm de comprimento Behuria capixaba

12'. Pétalas com margens eciliadas e ápice do ovário recoberto por tricomas de até $0,5 \mathrm{~mm}$ de comprimento Behuria mestrealvarensis

10'. Pétalas purpúreas ou roxas; estames com conectivo provido de apêndice espiralado ou enrolado (Dolichoura)

13. Arbustos; ramos 4-alados; hipanto vinoso, anteras (tecas) amarelas

Dolichoura kollmannii

13'. Plantas reptantes ou trepadeiras; ramos não alados; hipanto verde; anteras (tecas) brancas a roxas/purpúreas Dolichoura spiritusanctensis 
1. Behuria Cham., Linnaea 9: 376. 1834.

Arbustos. Ramos não fistulosos, com projeções glandulares sésseis ou com tricomas glandulares apenas sobre os nós. Folhas opostas, raro verticiladas, planas, acródromas. Inflorescências paniculadas ou cimosas, apicais. Flores pediceladas, 5-6-meras, diplostêmones; hipanto glandulosopontuado ou com tricomas glandulares sésseis; cálice apendiculado ou inapendiculado, com sépalas regulares; pétalas brancas ou rosadas, com ápice agudo a arredondado; estames 10-12, isomórficos, em conjunto zigomórfico, conectivo não prolongado abaixo das tecas, desprovido de glândula no dorso, com apêndice dorsal único, descendente, linear-subulado e reto ou levemente encurvado, antera reta e com o ápice levemente encurvado ventralmente, com ápice atenuado; ovário 3-4-locular, parcialmente súpero (adnado ao hipanto em sua base), ápice glabro ou com tricomas glandulares. Frutos capsulares (velatídio); sementes piramidais.

Behuria é um gênero exclusivo do Brasil, com 17 espécies (Tavares 2005; Bochorny et al. 2017a; Bochorny et al. 2017b). Tem distribuição restrita ao domínio da Mata Atlântica no Espírito Santo, Minas Gerais, Rio de Janeiro, São Paulo e Paraná. No Espírito Santo é representado por três espécies (Fig. 1a), sempre ocorrendo em áreas de Floresta Ombrófila Densa e Floresta Estacional Semidecidual, sobre afloramentos graníticos. Até 2008 o gênero era desconhecido no estado, e as três espécies aqui listadas foram descritas há menos de dez anos.

1.1. Behuria capixaba R. Goldenb. \& Reginato, J. Torrey Bot. Soc. 136: 293-301. $2009 . \quad$ Fig. 2a-c

Arbusto 1-1,5 m. alt. Ramos não alados. Folhas opostas, com pecíolo 6-14 mm compr.; lâmina 5-8 × 1-2,5 cm, lanceolada a elípticolanceolada, ápice acuminado, base obtusa, margem denticulado-ciliada, sem tufos de tricomas nos espaços entre os dentes, e revoluta, nervuras 3, basais, livres ou unidas na base e formando domácias na face abaxial, esta esparsamente recoberta por tricomas glandulares sésseis, não adensados na base das nervuras, próximo às domácias. Cimeiras (não dicásios) 1,5-3 cm compr. Flores 6-meras, sobre pedicelos 4-6 mm compr.; hipanto 3,5-4,5 $\times 4,5-5 \mathrm{~mm}$, verde, campanulado, glabro ou com tricomas glandulares sésseis; cálice com tubo ca. 1 $\mathrm{mm}$ compr., inapendiculado, com sépalas $1-3 \mathrm{~mm}$ compr., largamente triangulares a triangulares, ápice agudo, margem ciliada; pétalas $17-20 \times 10-15 \mathrm{~mm}$, rosadas, obovadas, ápice arredondado, margem inteira, ciliada, ápice com tricomas glandulares na face adaxial; estames com filetes 6,5-7,5 mm compr., conectivo com apêndice prolongado abaixo das tecas ca. $2 \mathrm{~mm}$ compr., cor desconhecida, reto, anteras ca. $5 \mathrm{~mm}$ compr., amarelas; ovário 3-4-locular, parcialmente súpero (adnado ao hipanto em sua base), ápice com tricomas glandulares esparsos 1,4-2,5 mm compr., estilete $9-11 \mathrm{~mm}$ compr.

Material examinado: Governador Lindenberg, 26.IV.2007, Demuner 3858 (MBML, RB, UPCB, VIES); 12.V.2015, Bochorny 143 (MBML, NY, RB, UEC, UPCB). Marilândia, 18.I.2006, Demuner 1653 (MBML, $\mathrm{RB}, \mathrm{UPCB}, \mathrm{VIES}$ ).

Behuria capixaba é encontrada somente no Espírito Santo (Goldenberg \& Reginato 2009). Ocorre em afloramentos graníticos, em região de Floresta Estacional Semidecidual, e dela são conhecidas apenas duas populações, nos municípios de Marilândia e Governador Lindenberg (Fig. 1a). Coletada com flores em janeiro e frutos em abril. Behuria capixaba pode ser distinta de $B$. comosa e $B$. mestrealvarensis pelas pétalas com margens ciliadas, e ápice do ovário com tricomas glandulares esparsos de 1,4-2,5 mm.

1.2. Behuria comosa Tavares, Baumgratz \& R. Goldenb., Bot. J. Linn. Soc. 158: 489-492. 2008.

Fig. 2d,e

Arbusto $0,1-0,4$ m. alt. Ramos não alados. Folhas verticiladas ou opostas, com pecíolo 1-2 mm compr.; lâmina 1,5-2 × 1-1,5 cm, elíptica a oval, ápice agudo, base obtusa, margem denticulado-ciliada, com tufos de tricomas nos espaços entre os dentes, e plana, nervuras 3-5, suprabasais, unidas na base formando domácias na face abaxial, esparsamente recoberta por tricomas glandulares curtamente pedicelados, estes sempre mais densos junto às domácias. Panículas 2,5-4 cm compr., multifloras. Flores 5(-6)-meras, sobre pedicelos 1-1,5 mm compr.; hipanto 2,5-3 $\times 3-3,5 \mathrm{~mm}$, verde ou vinoso, campanulado, glanduloso-pontuado; cálice com tubo ca. 0,3 mm compr., apendiculado, com sépalas ca. $1 \mathrm{~mm}$ compr., largamente triangulares, ápice agudo, margem eciliada; pétalas $10 \times 5 \mathrm{~mm}$, brancas e rosadas, obovadas, ápice agudo e apiculado, margem inteira, eciliada, glabras; estames com filetes 3-3,5 mm compr., conectivo com apêndice prolongado abaixo das tecas $1-1,2 \mathrm{~mm}$ compr., amarelo, reto ou encurvado, anteras $2,5-3 \mathrm{~mm}$ compr., amarelas; ovário 3-locular, parcialmente súpero (adnado ao hipanto em sua base), glabro, estilete $6,5-8,5 \mathrm{~mm}$ compr. 

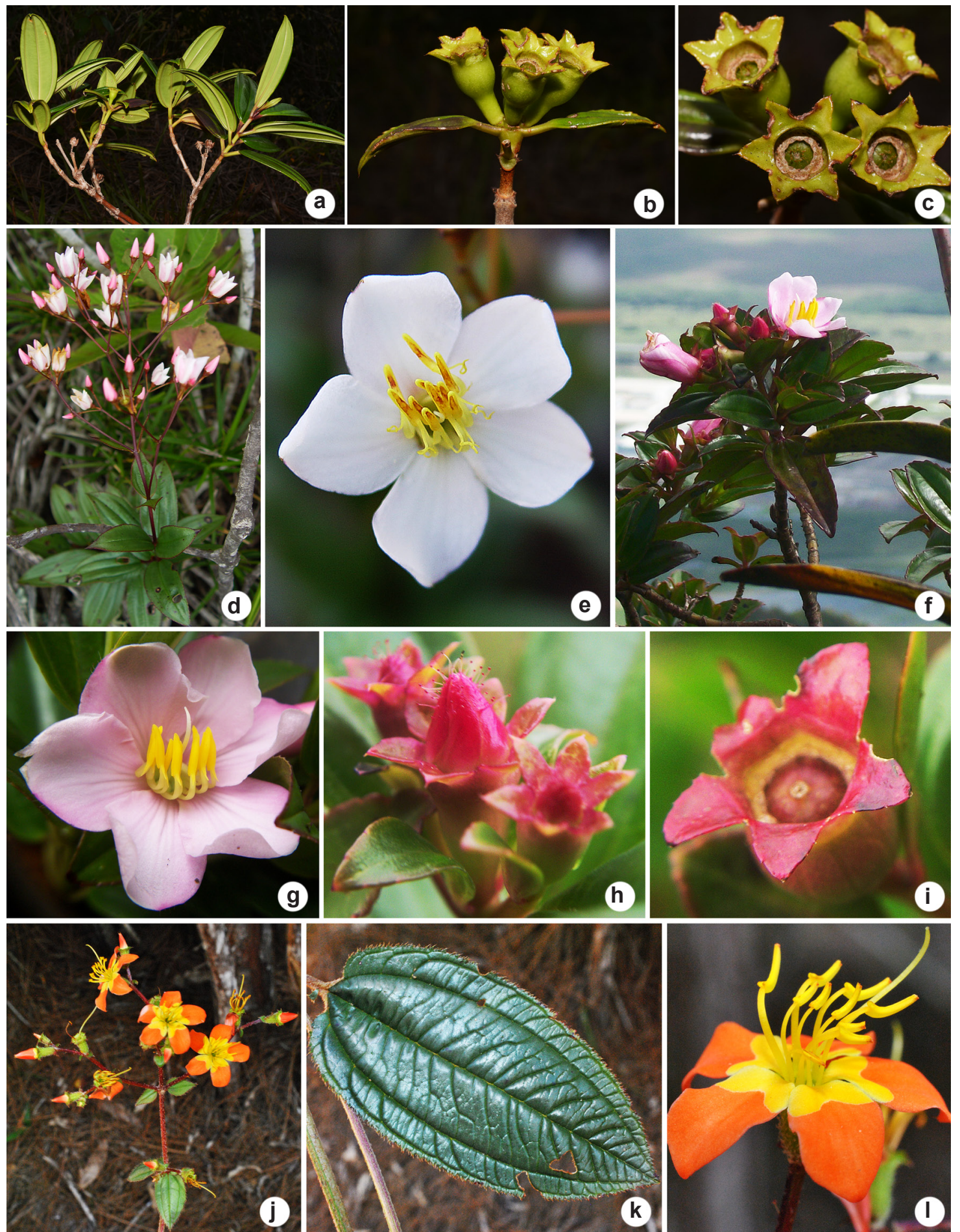

Figura 2 - a-1. Behuria e Cambessedesia no Espírito Santo - a-c. Behuria capixaba - a. ramo fértil; b. frutos imaturos, vista lateral; c. frutos imaturos, vista apical. d,e. Behuria comosa - d. ramo fértil; e. flor. f-i. Behuria mestrealvarensis - f. ramo fértil; g. flor; h. botão floral; i. fruto imaturo. j-1. Cambessedesia eichleri - j. ramo fértil; k. folha, superfície adaxial; 1. flor. Fotos: a-c,j-1. Renato Goldenberg; d,e. André Fontana; f-i. Diego Iglesias.

Figure 2 - a-l. Behuria and Cambessedesia in Espírito Santo - a-c. Behuria capixaba - a. fertile branch; b. young fruits, lateral view; c. young fruits, apical view. d,e. Behuria comosa - d. fertile branch; e. flower. f-i. Behuria mestrealvarensis - f. fertile branch; g. flower; h. flower bud; i. young fruit. j-1. Cambessedesia eichleri - j. fertile branch; k. leaf, adaxial surface; l. flower. Photos: a-c,j-1. Renato Goldenberg; d,e. André Fontana; f-i. Diego Iglesias. 
Material examinado: Itaguaçu, 23.IV.2005, Fontana 1371 (MBML). São Roque do Canaã, 19.III.2004, Fraga 1161 (MBML); 10.IV.2005, Fontana 1285 (MBML); 19.VII.2005, Fontana 1592 (MBML); 16.IX.2005, Fontana 1718 (MBML, UPCB); 27.VIII.2006, Esgario 89 (MBML); 20.III.2007, Esgario 154 (MBML, RB); 11.V.2007, Esgario 169 (MBML); 6.II.2011, Goldenberg 1518 (NY, UPCB).

Behuria comosa é encontrada em Minas Gerais e no Espírito Santo (Fig. 1a) (Tavares et al. 2008). Ocorre em afloramentos graníticos, em região de Floresta Ombrófila Densa. Coletada com flores entre fevereiro e junho e com frutos entre março e junho. Behuria comosa difere de $B$. mestrealvarensis e $B$. capixaba pelas pétalas com margens eciliadas e ápice do ovário glabro.

1.3. Behuria mestrealvarensis D. T. Iglesias \& R. Goldenb., Phytotaxa 255: 281-286. 2016.

Fig. $2 \mathrm{f}-\mathrm{i}$

Arbusto 0,6-1 m. alt. Ramos não alados. Folhas verticiladas ou opostas, com pecíolo 3-8 mm compr.; lâmina 1,8-4,6 × 1,1-2,3 cm, elíptica a oval, ápice agudo ou acuminado, base obtusa ou decurrente, margem serrulada, sem tufos de tricomas nos espaços entre os dentes, e plana, nervuras 3-5, suprabasais, unidas na base formando domácias na face abaxial, esta glabra. Dicásios ou flores isoladas 2,5-5 cm compr. Flores 5(-6)-meras, sobre pedicelos 1,5-2 mm compr.; hipanto 4-5 × 3,5 mm, verde ou com pontuações rosadas, campanulado, glabro; cálice com tubo ca. $1 \mathrm{~mm}$ compr., apendiculado, com sépalas 3,5-4,5 mm compr., largamente triangulares, ápice agudo, margem serrulada-ciliada; pétalas 12-13 × 6-8 mm, brancas e rosadas, obovadas e assimétricas, ápice arredondado, margem inteira, eciliada, ápice com tricomas glandulares na face abaxial; estames com filetes 5-7 mm compr., conectivo com apêndice prolongado abaixo das tecas ca. 1,5 mm compr., amarelo, reto ou encurvado, anteras 4,5-5 $\mathrm{mm}$ compr., amarelas; ovário 4-locular, parcialmente súpero (adnado ao hipanto em sua base), ápice com tricomas glandulares esparsos de até $0,5 \mathrm{~mm}$ compr., estilete 8,5-12 mm compr.

Material examinado: Serra, 21.XI.1982, Pirani 170 (SP, SPF); 11.XI.1990, Vinha 1166 (VIES); 24.II.2013, Iglesias \& Cardoso 98 (VIES); 15.I.2014, Iglesias 169 (VIES, MBML, NY, RB, UPCB); 15.I.2014, Iglesias 170 (VIES).

Behuria mestrealvarensis é encontrada somente no Espírito Santo (Iglesias et al. 2016). Ocorre em afloramentos graníticos, em região de Floresta Ombrófila Densa e dela é conhecida apenas uma população no município de Serra (Fig. 1a). Coletada com flores de novembro a fevereiro e com frutos em janeiro e fevereiro. Esta espécie difere de $B$. capixaba e $B$. comosa pelas pétalas com margens eciliadas e ápice do ovário recoberto por tricomas de até $0,5 \mathrm{~mm}$ compr.

2. Cambessedesia DC., Prodr. 3: 110. 1828.

Arbustos. Ramos não fistulosos, com tricomas glandulares ou glabros. Folhas opostas, planas, acródromas. Inflorescências em dicásios compostos, paucifloros, ou dicásio simples ou reduzidas a uma ou duas flores isoladas, apicais ou axilares. Flores pediceladas, 5-meras, diplostêmones; hipanto glabro, com tricomas glandulares ou com emergências; cálice inapendiculado, com sépalas regulares; pétalas amarelas ou vermelho-alaranjadas com base amarela, com ápice acuminado; estames 10, subisomórficos, em conjunto zigomórfico, conectivo não prolongado, desprovido de glândula no dorso, desprovido de apêndice, antera reta e com o ápice levemente encurvado dorsal ou ventralmente, com ápice subulado; ovário (2-)3-locular, súpero, ápice glabro ou revestido por tricomas glandulares. Frutos capsulares (velatídio); sementes ovais.

Cambessedesia é um gênero exclusivo do Brasil, com 26 espécies (Fidanza 2009; Fidanza \& Almeda 2011). Ocorre geralmente no domínio Cerrado, em campos rupestres, em Tocantins, Bahia, Pernambuco, Piauí, Distrito Federal, Goiás, Mato Grosso, Espírito Santo, Minas Gerais, Rio de Janeiro, São Paulo e Paraná. No Espírito Santo é representado por duas espécies (Fig. 1a), ocorrendo em Floresta Ombrófila Densa sobre afloramentos graníticos.

2.1. Cambessedesia eichleri Cogn. in Mart., Eichl. \& Urb., Fl. bras. 14(3): 11-12. 1883. Fig. 2j-1

Arbusto 0,3-1 m. alt. Ramos quadrangulares com tricomas. Folhas opostas, com pecíolo 4-5 mm compr.; lâmina 3-5,5 × 1-2,5 cm, oval, ápice agudo ou acuminado, base arredondada, margem serreada, nervuras 3, basais, face adaxial glabra, face abaxial com tricomas dendríticos nas nervuras. Dicásios simples, compostos ou reduzidos a uma ou duas flores isoladas 4-10 cm compr., apicais e axilares. Flores 5-meras, sobre pedicelos ca. $1 \mathrm{~mm}$ compr.; hipanto 4-5 × 2-3 mm, 10-estriado, campanulado, com tricomas dendríticos esparsos a densos; cálice com tubo ca. $1 \mathrm{~mm}$ compr., sépalas $0,8-1,2 \times 0,5-$ $0,7 \mathrm{~mm}$ compr., subuladas, ápice obtuso; pétalas 4-5 × 3-3,8 mm, predominantemente vermelho- 
alaranjadas com base amarela, ovais, ápice acuminado, margem inteira; estames antessépalos com filetes 5-5,5 mm; anteras 6-6,5 mm; estames antepétalos com filetes 4-4,5 mm compr.; anteras 4,5-5 mm compr.; ovário 3-locular, ápice glabro, estilete 9-10 mm compr.

Material examinado: Ibiraçu, 6.V.2005, Fontana 1418 (MBML, UPCB). Itaguaçu, 10.IV.2004, Fontana 824 (MBML, UPCB). Itarana, 19.IV.2013, Forzza 7528 (RB, UPCB). Santa Leopoldina, 15.III.2005, Fontana 1163 (MBML, UPCB); 10.V.2015, Bochorny 134 (MBML, NY, UPCB). Santa Teresa, 1.II.2000, Demuner 695 (MBML, UPCB); 31.I.2002, Kollmann 5444 (MBML, UPCB); 2.VI.2004, Vervloet 2672 (MBML, UPCB); 24.XI.2004, Kollmann 7255 (MBML, UPCB); 14.I.2012, Goldenberg 1627 (NY, UPCB). São Roque do Canaã, 23.II.2004, Fontana 738 (MBML, UPCB); 27.III.2004, Kollmann 6554 (MBML, UPCB); 23.III.2005, Fontana 1202 (MBML, UPCB); 30.VII.2006, Es gario 62 (MBML, UPCB); 30.I.2007, Esgario 113 (MBML, UPCB); 6.II.2011, Michelangeli 1599 (NY, UPCB). Serra, 19.XI.1988, s.c. (MBML 6392); 11.XI.1990, Vinha 1177 (VIES); 14.XI.2009, Gomes 3536 (VIES); 15.I.2014, Iglesias (VIES 38101).

Cambessedesia eichleri ocorre em Pernambuco, Espírito Santo e Minas Gerais (Fidanza 2009). No Espírito Santo ocorre sobre afloramentos graníticos em região de Floresta Ombrófila Densa (Fig. 1a). Coletada com flores em janeiro e fevereiro com frutos em fevereiro e maio. Cambessedesia eichleri difere de C. hilariana pela última possuir, folhas com pecíolo 2-3 mm compr.; lâmina $0,3-1,5 \times 0,2-0,8 \mathrm{~cm}$; ápice do ovário com tricomas glandulares.

A presença de tricomas dendríticos sobre o hipanto não foi notada por Fidanza (2009), embora boa parte do material aqui listado tenha sido examinado por esta autora. Estes tricomas podem ser muito esparsos e escassos, ou às vezes mais densos (i.e., os materiais coletados no município de Serra). A presença destes tricomas, por sua vez, caracteriza uma outra espécie, Cambessedesia angelana K. Fidanza \& Almeda (Fidanza \& Almeda 2011), recém-descrita para o leste de Minas Gerais. As plantas aqui listadas como $C$. eichleri, portanto, não diferem de C. angelana, mas não podemos sugerir sua sinonimização, visto que não tivemos acesso ao material tipo de C. eichleri, este proveniente de Minas Gerais. Em conclusão, todo o material capixaba pode ser (1) pertencente a $C$. angelana, caso o tipo de C. eichleri seja realmente diferente desta, ou (2) pertencente a $C$. eichleri e, neste caso, C. angelana seria um sinônimo de $C$. eichleri.
2.2. Cambessedesia hilariana (Kunth) DC., Prod. 3. 111. 1828.

Fig. 3a,b

Arbusto 0,2-0,6 m. alt. Ramos não alados. Folhas opostas, subsséseis ou com pecíolo 2-3 mm compr.; lâmina 0,3-1,5 × 0,2-0,8 cm, oval, elíptica ou linear-lanceolada, ápice agudo ou acuminado, base atenuada, margem inteira ou 1-3 denteadas, nervuras 1-2, basais, face adaxial glabra, face abaxial as vezes com tricomas glandulares. Dicásios simples, compostos ou reduzidos a uma ou duas flores isoladas, as vezes escorpióides, até $7 \mathrm{~cm}$ compr., apicais e axilares. Flores (4-)5(-6)-meras, sobre pedicelos $0,6-1 \mathrm{~mm}$ compr.; hipanto 4-4,5 × 1,7-1,8 mm, 10-estriado, campanulado, glabro ou com emergências glandulares sobre as estrias; cálice com tubo ca. $1 \mathrm{~mm}$ compr., sépalas 1,6-1,8 × 1,3-1,4 mm compr., triangulares, ápice obtuso; pétalas 5,5-5,8 × 2,6-2,8 mm, vermelhoalaranjadas com base amarela, ovais, ápice acuminado, margem inteira; estames antessépalos com filetes 3,3-4 mm compr.; anteras 3,5-2,7 mm compr.; estames antepétalos com filetes 4,3-4,5 mm compr.; anteras 6,8-7 mm compr.; ovário 3-4-locular, ápice com tricomas glandulares, estilete 9-10 mm compr.

Material examinado: Campo Onça, 10.II.1917 Luetzelburg 7167 (W- código da imagem: 19320005650).

Material adicional examinado: BRASIL. MINAS GERAIS: Grão Mogol, 13.VI.1990, Hatschbach 54236 (MBM, UPCB). Itabirito, 9.II.2013, Meyer 1492 (UPCB). Itutinga, 16.II.2012, Sobral 14752 (HUFSJ, UPCB). Joaquim Felício, 21.X.1999, Hatschbach 69443 (MBM, UPCB). Ouro Branco, 2.II.2011, Michelangeli 1569 (UPCB, NY). Ouro Preto, 4.II.2013, Meyer 1479 (UPCB). Santa Luzia, 2.II.1938, Mello Barreto 8978 (BHZB, UPCB). Santana do Riacho, 2.II.2013, Reginato 1416 (UPCB). SÃO PAULO: Itapeva, 29.X.2009, CieloFilho 1032 (SPSF, UPCB). Itararé, 13.I.2010, Mancinelli 1127 (UPCB).

Cambessedesia hilariana é encontrada em Tocantins, Piauí, Pernambuco, Bahia, Goiás, Distrito Federal, Minas Gerais, Espírito Santo, Rio de Janeiro, São Paulo e Paraná (Fidanza 2009). Apesar de $C$. hilariana apresentar a distribuição geográfica mais ampla no gênero (Fidanza 2009), apenas uma coleta no ano de 1917 (Luetzelburg 7167) é conhecida para o Espírito Santo, constando na etiqueta apenas a localidade "Campo Onça". Por ser este o único registro da espécie, nós utilizamos a imagem da exsicata depositada no herbário W (sigla segundo Thiers, continuamente atualizado) e materiais adicionais de Minas Gerais e São Paulo para a descrição. Devido à escassez de 

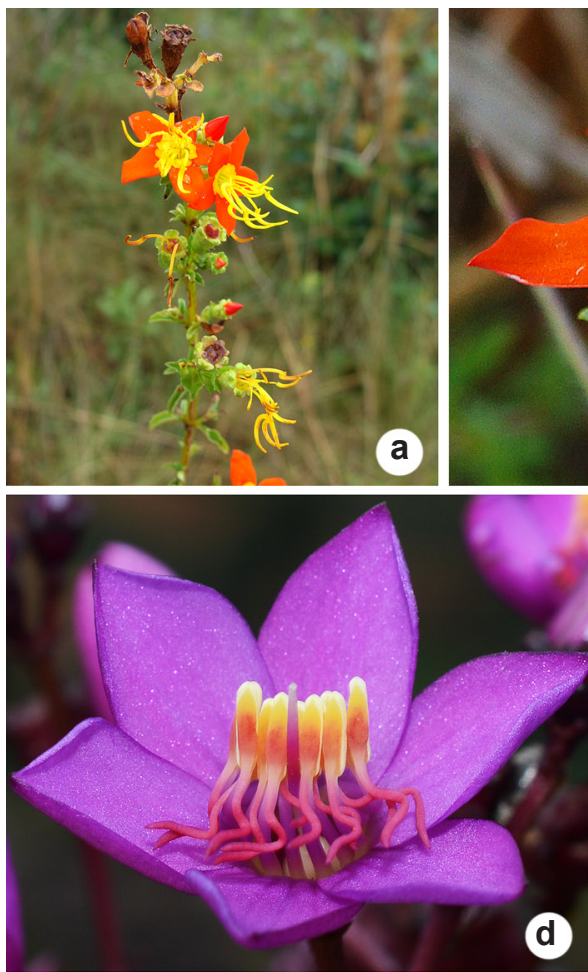

d)
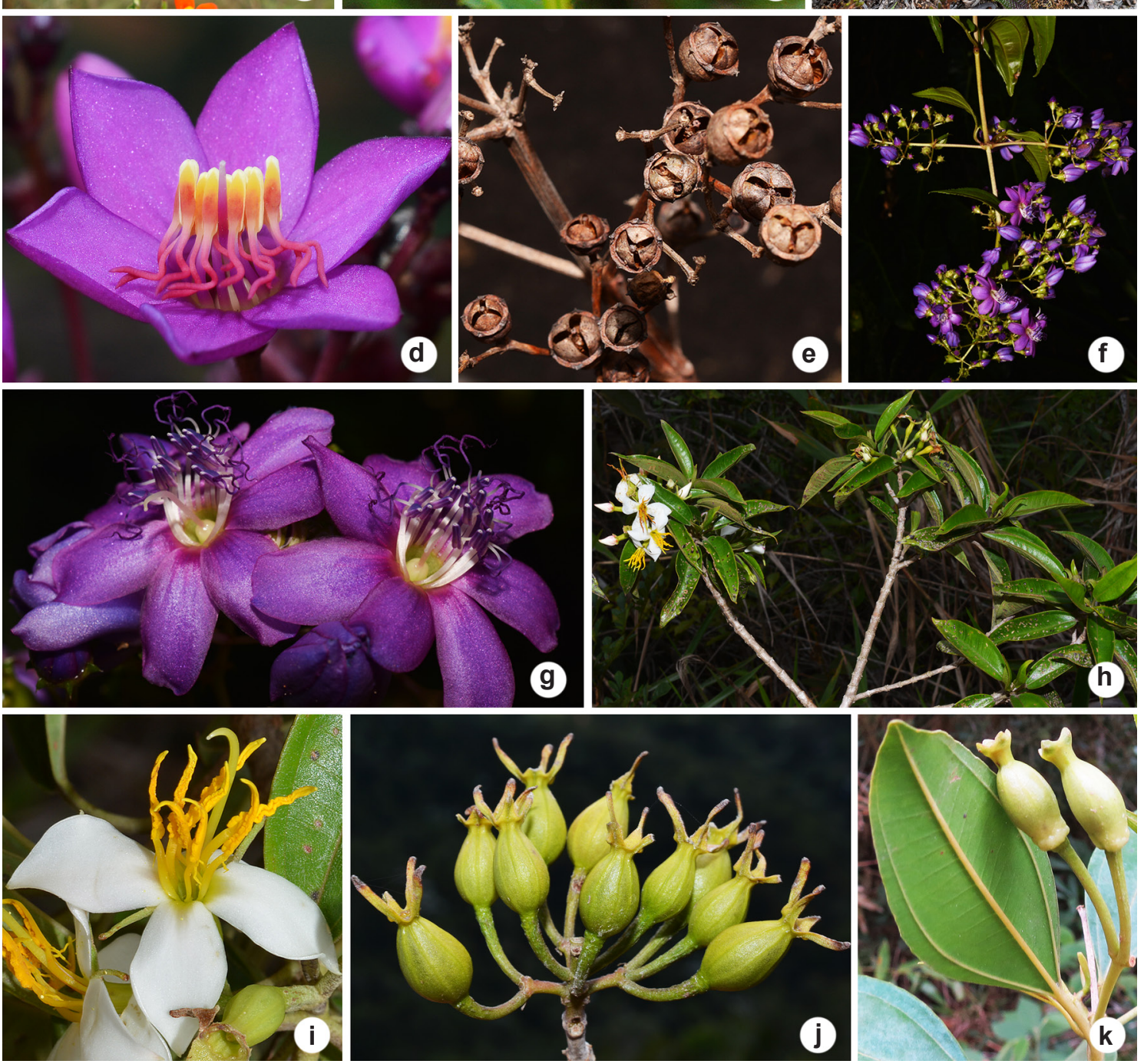

Figura 3 - a-k. Cambessedesia e Huberia no Espírito Santo - a,b. Cambessedesia hilariana - a. ramo fértil; b. flor; c-e. Dolichoura kollmannii - c. ramo fértil; d. flor; e. frutos maduros; f,g. Dolichoura spiritusanctensis - f. ramo fértil; g. flores; h-j. Huberia espiritosantenis - h. ramo fértil; i. flor; j. frutos imaturos; k. Huberia ovalifolia - frutos imaturos. Fotos: a,b. Lucas Bacci; c-j. Renato Goldenberg; k. Thuane Bochorny.

Figure 3 - a-k. Cambessedesia and Huberia in Espírito Santo - a,b. Cambessedesia hilariana - a. fertile branch; b. flower; c-e. Dolichoura kollmannii -c. fertile branch; d. flower; e. mature fruits; f,g. Dolichoura spiritusanctensis -f. fertile branch; g. flowers; $\mathrm{h}$-j. Huberia espiritosantenis -h. fertile branch; i. flower; j. young fruits; k. Huberia ovalifolia - young fruits. Photos: a,b. Lucas Bacci; c-j. Renato Goldenberg; k. Thuane Bochorny. 
coletas e informações no estado, nós apresentamos, na Figura 3, fotos da espécie provenientes de Minas Gerais (Fig. 3a,b). Também não foi possível descrever características do habitat, dados fenológicos e distribuição geográfica da espécie no Espírito Santo. Cambessedesia hilariana pode ser distinguida de $C$. eichleri pelas folhas com pecíolo 4-5 mm compr., lâmina com 3-5,5 × 1-2,5 cm e ápice do ovário glabro.

3. Dolichoura Brade, Arch. Jard. Bot. Rio de Janeiro 16: 12.1959.

Arbustos ou trepadeiras. Ramos não fistulosos, com tricomas glandulares. Folhas opostas, planas, acródromas. Inflorescências paniculadas, apicais, multifloras. Flores pediceladas, 6-7-meras, diplostêmones; hipanto glabro ou com tricomas glandulares sésseis ou pedicelados; cálice apendiculado, com sépalas regulares; pétalas purpúreas ou roxas, com ápice agudo ou obtuso a arredondado; estames (12-)14, isomórficos, em conjunto zigomórfico, conectivo não prolongado, desprovido de glândula no dorso, com apêndice dorsal único, descendente, espiralado ou enrolado, antera reta e com o ápice levemente encurvado dorsal ou ventralmente, com ápice arredondado; ovário (2-)3(-4)-locular, parcialmente súpero (adnado ao hipanto em sua base) ou súpero, ápice glabro. Frutos capsulares (velatídio); sementes cuneadas a longo-cuneadas.

Dolichoura foi coletada, até o momento, apenas no Espírito Santo, na região serrana (Fig. 1b). São duas espécies que podem ser reconhecidas pelas flores 6-7-meras, com pétalas roxas ou purpúreas, e pelos estames com apêndices dorsais espiralados ou enrolados. Uma das espécies, D. spiritusanctensis, tem plantas trepadeiras ou reptantes, distintas de todas as demais no clado de Merianthera e gênero afins. Dolichoura pode ser encontrada em Floresta Ombrófila Densa, sobre afloramentos graníticos.

3.1. Dolichoura spiritusanctensis Brade, Arch. Jard. Bot. Rio de Janeiro 16: 12. 1959. Fig. 3f,g Reptante ou trepadeira próxima ao solo. Ramos não alados. Folhas com pecíolo 7-20 mm compr.; lâmina 3-7 × 1,5-4,5 cm, elíptica a oval, ápice acuminado e apiculado, base cordada a arredondada, margem denticulada, eciliada e revoluta, nervuras $3+2$, basais, face abaxial esparsamente recoberta por tricomas glandulares sésseis ou curtamente pedicelados. Panículas 6-17 cm compr. Flores (6-)7-meras, sobre pedicelos 1,52,5 mm compr.; hipanto 1,5-2 $\times 2,5-3,5 \mathrm{~mm}$, verde, campanulado, esparso a moderadamente recoberto por tricomas glandulares sésseis ou pedicelados; cálice com tubo ca. 0,5 compr., sépalas ca. 0,7 mm compr., triangulares, ápice agudo, apêndice dorsal longitudinalmente achatado, com ápice mucronado; pétalas 5-8 × 2,5-4 mm, roxas, obovadas a elípticas, ápice obtuso, truncado a levemente emarginado, margem inteira, eciliada; estames com filetes 2-3 mm compr., conectivo com apêndice 4-6 compr., branco na base e roxo em quase toda sua extensão, enrolado, anteras 2-2,5 mm compr., brancas a roxas/purpúreas; ovário 3(-4)-locular, súpero ou parcialmente súpero (adnado ao hipanto em sua base), estilete 4-5 mm compr.

Material examinado: Fundão, 25.VII.2000, Demuner 1258 (MBML, RB, UPCB); 30.XII.2002, Fontana 442 (MBML, RB, UPCB). Santa Leopoldina, 14.II.2006, Demuner 1783 (MBML, RB); 30.III.2006, Demuner 2153 (MBML, RB); 15.III.2007, Kollmann 9515 (MBML, RB); 15.IV.2008, Kollmann 10852 (MBML, RB). Santa Teresa, 23.XI.1953, Duarte 3674 (RB); 1.VIII.1984, Vimercat 217 (MBML, UPCB, US); 31.I.1986, Pizziolo 279 (CEPEC, MBML, UPCB, US); 11.III.1986, Fernandes 1891 (MBML, RB, UPCB, US); 3.III.1995, Chamas 62 (MBML); 24.II.1996, Lombardi 1078 (HUFU, MBM); 24.II.1996, Lombardi 1096 (HUFU, MBM); 28.I.1997, Hupp 66 (MBML, RB, UPCB); I.1997, Sobral 8283 (MBM); 11.XII.1997, Varassin 01 (MBML, RB, UPCB); 24.III.1998, Varassin 18 (MBML, RB, UPCB); 28.XII.1998, Kollmann 1427 (MBML, RB, UPCB); 24.III.1999, Kollmann 2247 (MBML, RB, UPCB); 27.V.1999, Lopes 753 (MBML, RB); 22.III.2000, Demuner 824 (MBML, RB, UPCB); 22.III.2005, Kollmann 7533 (MBML, UPCB); 17.XI.2005, Kollmann 8444 (MBML, UPCB); 19.I.2006, Kollmann 8551 (MBML, RB, UPCB); 17.II.2006, Britto 39 (MBML); 28.XI.2006, Lucas 755 (RB, UPCB); 11.VII.2007, Labiak 4029 (MBML, NY, RB, UPCB); 5.V.2009, Fontana 6009 (MBML); 12.XII.2009, Kollmann 11846 (MBML); 8.II.2011, Michelangeli 1611 (NY, RB, UPCB); 14.I.2012, Goldenberg 1626 (RB, UPCB).

Dolichoura spiritusanctensis ocorre apenas na região serrana do Espírito Santo (Fig. 1b) na Floresta Ombrófila Densa (Goldenberg \& Tavares 2007). Foi coletada com flores em julho, e entre novembro e março e com frutos entre janeiro e abril. Esta espécie pode ser distinta de $D$. kollmannii pelo hábito reptante/trepadeira, ramos não alados, hipanto vinoso e anteras (tecas) brancas a roxas/purpúreas.

3.2. Dolichoura kollmannii R. Goldenb. \& Tavares, Brittonia 59: 227. 2007.

Fig. 3c-e

Arbusto 20-40 cm. alt. Ramos 4-alados. Folhas com pecíolo 1-3 mm compr.; lâmina 2-7 
$\times$ 1-4 cm, elíptica a oval, ápice arredondado a agudo, base cordada, margem denticulado-ciliada e fortemente revoluta, nervuras $3-5$, basais, face abaxial esparsamente recoberta por tricomas glandulares sésseis ou curtamente pedicelados. Panículas 5-15 cm compr. Flores 6-meras, sobre pedicelos ca. $1 \mathrm{~mm}$ compr.; hipanto 1,5-2 $\times$ 2,5-3 mm, vinoso, campanulado, glabro; cálice com tubo ca. 0,5 compr., sépalas ca. $0,7 \mathrm{~mm}$ compr., triangulares, ápice agudo, apêndice dorsal crasso, com ápice obtuso; pétalas 4,5-8 $\times 2,5-4,5 \mathrm{~mm}$, purpúreas, obovadas a elípticas, ápice agudo, margem inteira, eciliada; estames com filetes 3,5-4,5 mm compr., conectivo com apêndice 3,5-4,5 $\mathrm{mm}$ compr., branco na base e purpúreo-avermelhado em quase toda sua extensão, espiralado, anteras 2-2,5 mm compr., amarelas; ovário (2-)3-locular, parcialmente súpero (adnado ao hipanto em sua base), estilete 7-7,5 $\mathrm{mm}$ compr. Material examinado: Santa Leopoldina, 15.III.2005, Kollmann 7420 (MBML, RB, UPCB); 15.III.2005, Fontana 1160 (MBML, RB, UPCB); 25.IV.2013, Kollmann 12670 (MBML, RB, UPCB); 10.V.2015, Bochorny 135 (MBML, RB, UEC, UPCB).

Encontrada apenas em uma localidade, no Espírito Santo (Fig. 1b), e ocorre em afloramentos graníticos em região de Floresta Ombrófila Densa (Goldenberg \& Tavares 2007). Coletada com flores entre março e abril e com frutos entre abril e maio. Essa espécie difere de D. spiritusanctensis pelo hábito arbustivo, ramos 4-alados, hipanto verde e anteras (tecas) amarelas.

\section{Huberia DC., Prodr. 3: 167. 1828.}

Árvores ou arvoretas. Ramos não fistulosos, com tricomas simples ou glandulares. Folhas opostas, planas, acródromas. Inflorescências cimosas, apicais. Flores pediceladas, 4-meras, diplostêmones; hipanto glabro; cálice inapendiculado, com sépalas regulares; pétalas brancas, com ápice arredondado a obtuso ou agudo; estames 8 , isomórficos, em conjunto zigomórfico, conectivo não prolongado, desprovido de glândula no dorso, com apêndice dorsal único, descendente, filiforme, antera dorsalmente ou ventralmente arqueadas, ápice subulado; ovário 4-locular, parcialmente súpero (adnado ao hipanto em sua base), ápice glabro. Frutos capsulares (ruptídio); sementes alongadas.

Huberia ocorre no Peru, Equador e Brasil, com 16 espécies (Baumgratz 2004; Goldenberg et al. 2016). No Brasil tem distribuição restrita ao domínio da Mata Atlântica, presente desde
Pernambuco até o Rio Grande do Sul (Baumgratz 2004). No Espírito Santo é representado por duas espécies (Fig. 1b), ocorrendo em áreas de Formação Pioneira sob influência marinha ou associada a afloramentos rochosos na Floresta Ombrófila Densa.

\subsection{Huberia espiritosantensis Baumgratz,} Rodriguésia 50: 39. 1999. Fig. $3 h-j$

Arvoretas ou árvores 2-6 m. alt. Ramos não alados, com tricomas glandulares. Folhas opostas, com pecíolo 10-20 mm compr.; lâmina 4-12 × 1,5-5 cm, elíptica, estreitamente elíptica a oval, ápice agudo a acuminado, base obtusa a arredondada, margem inteira, plana, nervuras 3, basais, livres, face abaxial glabra ou esparsamente recoberta por tricomas glandulares sobre as nervuras. Inflorescências 1,5-7,5 cm compr. Flores sobre pedicelos 7-10 mm compr.; hipanto 6-7 $\times$ 2-2,5 mm, verde, tubuloso-urceolado; cálice com tubo ca. $1 \mathrm{~mm}$ compr., sépalas 5,5-7 mm compr., oblongo-lineares, ápice arredondado; pétalas 10-13 $\times 4,5-5,5 \mathrm{~mm}$, brancas, obovadas, ápice agudo a obtuso, margem denticulada, eciliada; estames com filetes 5,5-6,5 mm compr., conectivo com apêndice 2-3 mm compr., amarelo, anteras $7-9 \mathrm{~mm}$ compr., amarelas, mais ou menos retas e com o ápice ventralmente arqueado; estilete 16-19 mm compr. Material examinado: Águia Branca, 26.VII.2006, Magnago 1107 (MBML, UPCB); 3.IV.2007, Demuner 3498 (MBML, RB). Afonso Cláudio, 16.VII.2007, Kollmann 9907 (MBML, UPCB). Água Doce do Norte, 28.IV.2008, Fontana 5098 (MBML). Colatina, 12.VII.2006, Demuner 2587 (MBML, RB, UPCB); 20.III.2007, Demuner 3266 (MBML, RB). Fundão, 15.IX.1998, Kollmann 541 (MBML, UPCB); 9.III.2003, Fontana 518 (MBML, RB, UPCB). Governador Lindenberg, 26.IV.2007, Demuner 3844 (MBML, UPCB). Ibiraçu, 6.V.2005, Fontana 1417 (MBML, UPCB); 7.II.2007, Fontana 2801 (MBML, RB, UPCB). Marilândia, 21.III.2007, Demuner 3285 (MBML, RB); 21.III.2007, Demuner 3289 (MBML, RB, UPCB). Pancas, 7.III.2003, Fraga 966 (MBML, RB, UPCB); 13.III.2016, Forzza 8757 (RB, UPCB). Santa Leopoldina, 15.III.2005, Fontana 1174 (MBML, RB, UPCB); 4.VI.2015, Goldenberg 2216 (UPCB); 10.V.2015 Bochorny 138 (MBML, NY, RB, UEC, UPCB). Santa Teresa, 11.IV.1988, Fernandes 2450 (MBML, UPCB); 13.III.1990, Fernandes 2906 (MBML, UPCB); 12.IV.1995, Chamas 69 (MBML, RB, UPCB); 11.II.1999, Kollmann 1951 (MBM, MBML, RB, UPCB); 5.V.1999, Lopes 633 (MBML, RB, UPCB); 1.II.2000, Demuner 670 (MBML, RB, UPCB); 16.V.2000, Demuner 1064 (MBML, RB, UPCB); 16.V.2000, Demuner 1071 (MBML, RB, UPCB); 1.VI.2000, 
Kollmann 2977 (MBML, RB, UPCB); 10.VII.2001, Kollmann 4104 (MBML, RB). São Roque do Canaã, 24.XII.2003, Fontana 677 (MBML, RB, UPCB); 15.XI.2004, Fontana 1066(MBML, UPCB); 17.V.2007, Kollmann 9791 (MBML, UPCB). Viana, 19.I.2009, Goldenberg 1258 (MBML, RB, UPCB); 12.IV.2009, Goldenberg 1448 (RB, UPCB).

Encontrada apenas no Espírito Santo (Baumgratz 2004; Fig. 1b), ocorrendo em Floresta Ombrófila Densa e na Floresta Estacional Semidecidual, que rodeia afloramentos graníticos, ou ainda sobre afloramentos graníticos. Coletada com flores entre março e abril e com frutos entre abril e maio. Huberia espiritosantensis é morfologicamente parecida com $H$. ovalifolia mas difere desta pelas sépalas oblongo-lineares com 5,5-7 mm comprimento e pétalas de 10-13 $\times 4,5-5,5 \mathrm{~mm}$ com margem denticulada.

4.2. Huberia ovalifolia DC., Prodr. 3: 167. 1828.

Fig. 3k

Arvoretas ou árvores 3-6 m. alt. Ramos não alados, com tricomas não glandulares. Folhas opostas, com pecíolo 10-30 mm compr.; lâmina 5-12 × 2,5-5,5 cm, elíptica, estreitamente elíptica a oval, ápice agudo a obtuso, base obtusa a arredondada, margem inteira, plana, nervuras 3 , basais, livres, face abaxial glabra ou esparsamente recoberta por tricomas não glandulares. Inflorescências 4,5-9 cm compr. Flores sobre pedicelos 10-20 mm compr.; hipanto 7-11 × 2,5-3 mm, verde, tubuloso-urceolado; cálice com tubo ca. $1 \mathrm{~mm}$ compr., sépalas 1,5-2 mm compr., largamente triangulares, ápice arredondado; pétalas $20 \times 10 \mathrm{~mm}$, brancas, obovadas, ápice obtuso a arredondado, margem ondulada, eciliada; estames com filetes $7-10 \mathrm{~mm}$ compr., conectivo com apêndice 5-7 mm compr., amarelo, anteras 10-12 mm compr., amarelas, dorsalmente arqueadas; estilete 25-30 mm compr. Material examinado: Conceição da Barra, 15.V.1987, Lima 2981 (RB); 27.III.1992, Pereira 3238 (VIES); 24.VI.1992, Pereira 3575 (SP, VIES); 5.XI.1996, Pereira 5698 (UPCB, VIES); Pereira 3575 (SPF, VIES); 28.VIII.2012, Flores 1209 (RB, VIES, UPCB). Linhares, 16.II.1981, Silva 237 (CEPEC, CVRD, SP); 29.V.1990, Folli 1136 (CVRD); 20.II.1992, Pereira 2781 (UPCB, VIES); 18.V.1994, Folli 2310 (CVRD). Sooretama, 13.V.2009, Colleta 268 (ESA, UPCB).

Huberia ovalifolia ocorre na Bahia, Minas Gerais, Espírito Santo, Rio de Janeiro e São Paulo (Baumgratz 2004). No Espírito Santo pode ser encontrada tanto em áreas de Formação Pioneira sob influência marinha e na Floresta
Ombrófila Densa (Fig. 1b). Coletada com flores entre novembro e fevereiro e com frutos em maio. Huberia ovalifolia é morfologicamente parecida com $H$. espiritosantensis mas difere desta pelas sépalas largamente triangulares com 1,5-2 mm compr. e pétalas com cerca de $20 \times 10 \mathrm{~mm}$ com margem ondulada.

5. Merianthera Kuhlm., Arq. Inst. Biol. Veg. 1: 231-233. 1935.

Arbustos ou arvoretas. Ramos fistulosos ou não, com tricomas glandulares, depois glabrescentes. Folhas opostas, planas, acródromas. Inflorescências paniculadas, cimeiras depauperadas ou reduzidas a flores isoladas. Flores pediceladas, (5-)6-meras, diplostêmones; hipanto glandulosopontuado; cálice apendiculado ou inapendiculado, com sépalas regulares ou irregulares; pétalas roxas, com ápice arredondado, truncado ou obtuso; estames (10-)12, fortemente dimórficos, em conjunto zigomórfico, conectivo prolongado, desprovido de glândula no dorso, com dois apêndices dorsais, um ereto, espesso, reto e com ápice bífido, o outro descendente, curto e triangular, antera dorsalmente arqueada, com ápice subulado; ovário 4-5-locular, ínfero, ápice glabro ou revestido por tricomas glandulares. Frutos capsulares (ruptídio); sementes piramidais.

Merianthera é um gênero exclusivo do Brasil, com sete espécies (Goldenberg et al. 2012). Tem distribuição restrita ao domínio da Mata Atlântica sobre afloramentos rochosos no Espírito Santo, Minas Gerais e no sul da Bahia. No Espírito Santo é representado por cinco espécies (Fig. 1c).

5.1. Merianthera bullata R. Goldenb., Fraga \& A. P. Fontana, Taxon 61: 1047. 2012. Fig. 4a-c

Arbustos 0,5-2,5 m. alt. Ramos não fistulosos, com tricomas glandulares. Folhas opostas, com pecíolo 7-26 mm compr.; lâmina 4,1-18 × 4,4-20 cm; orbicular, ápice arredondado, truncado a emarginado, base truncada a cordada, margem inteira, plana, nervuras 5-7, com um par de nervuras submarginais, suprabasais (3-9 $\mathrm{mm}$ ), face abaxial recoberta por tricomas glandulares esparsos. Panículas 3-7 × 4,1-10 cm compr., apicais. Flores com pedicelos 10-18 mm compr.; hipanto $7-10 \times 6-7 \mathrm{~mm}$, levemente costado e liso; cálice inapendiculado, com tubo ausente ou até 0,4 mm compr., sépalas regulares 2,4-4,1 mm compr., triangulares; pétalas 14-25 × 11-17 mm, rosas, obovadas, ápice arredondado; estames 10 , filamentos roxos, achatados, antessépalos com 

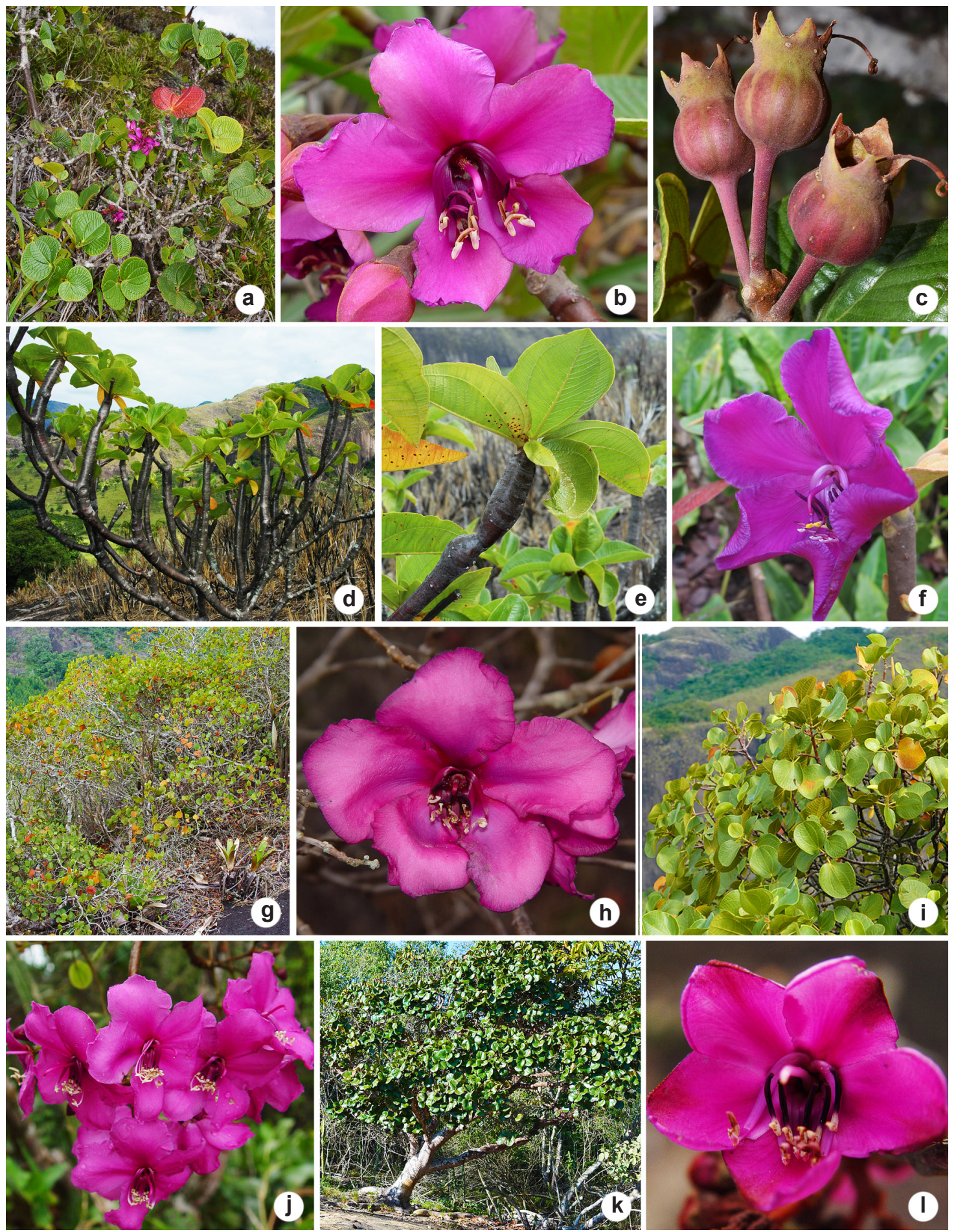

Figura 4 - a-l. Merianthera no Espírito Santo - a-c. Merianthera bullata - a. ramo fértil; b. flor; c. frutos imaturos. d-f. Merianthera burlemarxii -d. arbusto; e. ramo com folhas; f. flor. g,h. Merianthera parvifolia - g. arbusto; h. flor. i,j. Merianthera pulchra - i. ramos estéreis; j. inflorescência. k,l. Merianthera verrucosa - k. árvore em afloramento granítico; 1. flor. Fotos: a-e,i,k. Renato Goldenberg; f,j,l. Claudio Fraga; g,h. André Fontana.

Figure 4-a-1. Merianthera in Espírito Santo-a-c. Merianthera bullata - a. fertile branch; b. flower; c. young fruits. d-f. Merianthera burlemarxii -d. shrub; e. branch with leaves; f. flower. g,h. Merianthera parvifolia - g. shrub; h. flower. i,j. Merianthera pulchra $-\mathrm{i}$. sterile branches; $;$. inflorescence. k,l. Merianthera verrucosa - k. tree on a granitic outcrop; l. flower. Fotos: a-e,i,k. Renato Goldenberg; f,j,l. Claudio Fraga; g,h. André Fontana. 
apêndice ereto rosado, conectivo com apêndice descendente branco, anteras 5-7,2 mm compr., antepétalos com apêndice ereto branco, conectivo com apêndice descendente branco, anteras 6,8-9,3 mm compr.; ovário 6,1-7 mm compr., 5-locular, esparsamente revestido por tricomas glandulares, estilete 15-17 mm compr.

Material examinado: Fundão, 8.II.2007, Fontana 2839 (MBML, RB). Santa Leopoldina, 15.III.2005, Fontana 1175 (MBML, UPCB); 17.V.2006, Magnago 997 (MBML). Santa Teresa, 31.III.1999, Kollmann 2334 (MBML, RB, UPCB); 20.IV.2005, Fontana \& Esgario 1330 (MBML, UPCB); 29.IV.2005, Fontana 1404 (MBML, UPCB). São Roque do Canaã, 27.VIII.2006, Brito 112 (MBML, RB); 27.VIII.2006, Esgario 88 (MBML,RB); 17.V.2007, Fontana 3331 (MBML); 5.VII.2007, Kollman 9840 (MBML); 6.II.2011, Michelangeli 1598 (NY, UPCB).

Merianthera bullata ocorre somente no Espírito Santo (Fig. 1c) sobre afloramentos graníticos em Floresta Ombrófila Densa (Goldenberg et al. 2012). Coletada com flores em março, abril, maio e julho e com frutos fevereiro e abril. Esta espécie é semelhante a $M$. verrucosa por ter lóbulos regulares do cálice e folhas glabras, mas difere desta pela superfície lisa e não verrucosa do hipanto e pelo cálice inapendiculado.

\subsection{Merianthera burlemarxii Wurdack,} Phytologia 55: 133-134. 1984. Fig. 4d-f

Arbustos 0,4-2,5 m. alt. Ramos fistulosos, com tricomas glandulares. Folhas opostas, subsséseis ou com pecíolo até $15 \mathrm{~mm}$ compr.; lâmina 4,6-11 ×3,2-7,6 cm; elíptica a amplamente elíptica ou amplamente ovada, ápice acuminado a abruptamente acuminado, base obtusa a arredondada, raramente cordada, margem inteira, plana, nervuras 5-7, com um par de nervuras submarginais, basais a suprabasais (até $3 \mathrm{~mm}$ ), face abaxial esparsa a densamente recoberta por tricomas glandulares. Flores isoladas, subapicais. Flores com pedicelos 3,8-5,3 mm compr.; hipanto 6-9,4 × 5,6-6,7 mm, nitidamente costado e liso; cálice apendiculado, com tubo 1,2-1,5 mm compr., sépalas regulares 4-6,2 mm compr., triangulares; pétalas 23-30 × 16-27 mm, roxas, obovadas a amplamente obovadas, ápice arredondado; estames 10, filamentos roxos, achatados, antessépalos com apêndice ereto branco, conectivo com apêndice descendente branco a rosado, anteras 4,5-8,3 mm compr., antepétalos com apêndice ereto branco na base e amarelo no ápice, conectivo com apêndice descendente branco, inconspícuo, anteras 7-12 mm compr.; ovário ca. 4,5 mm compr., 5-locular, glabro ou esparsamente revestido por tricomas glandulares, estilete 13-16 mm compr.

Material examinado: Águia Branca, 26.IV.2006, Demuner 2250 (MBML); 18.X.2006, Demuner 2925 (MBML); 11.V.2008, Goldenberg 1154 (MBML, UPCB). Colatina, 13.IV.1978, Darke D-98 (US); 24.IX.1983, Hutchison 8472 (US). Nova Venécia, 15.I.2009, Fontana 5797 (MBML, RB). Pancas, 8.IX.1977, Shepherd 5875 (UEC); 30.X.2003, Fraga 1088 (RB); 18.XI.2009, Forzza 5747 (MBML, RB).

Merianthera burlemarxii ocorre apenas no Espírito Santo, em afloramentos graníticos na Floresta Estacional Semidecidual (Fig. 1c; Goldenberg et al. 2012). Também pode ser encontrada cultivada no Instituto Nacional da Mata Atlântica no município de Santa Teresa. Coletada com flores em janeiro, abril, setembro, outubro e novembro e com frutos em abril e outubro. Esta espécie pode ser diferenciada de todas as demais espécies do gênero pelos ramos fistulosos (Ziemmer et al. 2017), folhas acuminadas e flores isoladas.

5.3. Merianthera parvifolia $\mathrm{R}$. Goldenb., Fraga \& A. P. Fontana, Taxon 61: 1050. 2012. Fig. 4g,h Arbustos 1-1,8 m. alt. Ramos não fistulosos, com tricomas glandulares. Folhas opostas, sésseis ou com pecíolo 3-9 mm compr.; lâmina 2,5-7,8 $\times 2,5-10,3 \mathrm{~cm}$; arredondada a orbicular, ápice arredondado a amplamente arredondado ou truncado, base truncada a amplamente arredondada ou amplamente cordada, margem inteira, plana, nervuras 3-5, às vezes com um par de nervuras submarginais, suprabasais (1-5 mm), face abaxial moderadamente recoberta por tricomas glandulares ou glabras. Racemos depauperados, reduzidos a tríades ou díades 5-10 mm compr., apicais. Flores com pedicelos 3,5-8(-16) mm compr.; hipanto 8,5-12 × 6-11 mm, levemente costado e rugoso; cálice inapendiculado, com sépalas irregulares; pétalas 21-34 × 15-30 $\mathrm{mm}$, roxas, obovadas, ápice arredondado ou levemente cuculado, as vezes emarginado; estames 10, filamentos roxos, achatados, antessépalos com apêndice ereto branco, conectivo com apêndice descendente amarelado, anteras 5,5-7 mm compr., antepétalos com apêndice ereto branco, conectivo com apêndice descendente amarelo, anteras 8-9 mm compr.; ovário 5-6,3 mm compr., (4-)5-locular, esparsamente revestido por tricomas glandulares, estilete 13,5-15 mm compr. Material examinado: Água Doce do Norte, 28.IX.2008, Kollmann 10982 (MBML, UPCB). Águia Branca, 18.V.2007, Demuner 3997 (MBML); 18.V. 2007, Demuner 4009 (MBML). Colatina, 12.VII.2006, 
Demuner 2579 (MBML). Marilândia, 18.IV.2006, Magnago 861 (MBML); 26.VII.2006, Magnago 1120 (MBML); 26.VII.2006, Magnago 1399 (MBML); 3.XII.2006, Demuner 2598 (MBML); 21.III.2007, Demuner 3298 (MBML); 13.VI.2007, Demuner 4233 (MBML). Nova Venécia, 10.V.2008, Goldenberg 1141 (MBML, RB, UPCB); 14.I.2009, Fontana 5770 (MBML, RB). Santa Teresa, 20.VI.2000, Kollmann 3025 (MBML, RB, UPCB); 20.VI.2000, Demuner 1191 (MBML, RB, UPCB). São Roque do Canaã, 9.VII.2005, Fontana 1548 (MBML, RB, UPCB); 14.I.2008, Saavedra 641(MBML, RB, UPCB).

Merianthera parvifolia ocorre apenas no Espírito Santo, em afloramentos graníticos na Floresta Estacional Semidecidual e na Floresta Ombrófila Densa (Fig. 1c; Goldenberg et al. 2012). Coletada com flores entre abril e julho e frutos em janeiro, abril e julho. Esta espécie é similar a $M$. pulchra, mas difere desta pelas folhas subsésseis ou com pecíolos curtos e inflorescência reduzida.

5.4. Merianthera pulchra Kuhlm., Arq. Inst. Biol. Veg. 1: 233. 1935. Fig. 4i,j

Arbustos a árvores 2-6 m. alt. Ramos não fistulosos, com tricomas glandulares. Folhas opostas com pecíolo 12-29 mm compr.; lâmina 5-12 × 4-10,4 cm; elíptica a orbicular, ápice arredondado, truncado ou amplamente emarginado, base truncada a amplamente cordada, margem inteira, plana, nervuras 5-7, com um par de nervuras submarginais, levemente suprabasais $(2-4,5 \mathrm{~mm})$, face adaxial recoberta por esparsos tricomas, cedo glabrescente, face abaxial com tricomas glandulares esparsos. Panículas 7,3-13,5 × 9,8-15,5 cm compr., apicais. Flores com pedicelos 10-16 mm compr.; hipanto 6,4-7 × 3,2-6,1 mm, levemente costado e liso; cálice inapendiculado, com sépalas irregulares; pétalas 15,3-18,7 × 12-15,3 mm, roxas, obovadas, ápice arredondado a truncado; estames $10(-12)$, filamentos roxos tornando-se rosados para o ápice, achatados, antessépalos com apêndice ereto branco, conectivo com apêndice descendente branco, anteras 5,2-6 mm compr., antepétalos com apêndice ereto branco, conectivo com apêndice descendente branco, anteras 6,2-7 mm compr.; ovário 4,7-5 $\mathrm{mm}$ compr., (4-)5-locular, esparsamente revestido por tricomas glandulares, estilete 14-16 mm compr.

Material examinado: Águia Branca, 18.X.2006, Demuner 2967 (MBML); 3.X.2007, Fernandes 3419 (MBML); 11.V.2008, Goldenberg 1153 (MBML, RB,
UPCB). Colatina, 19.IX.1930, Kuhlmann 361 (RB). Ibiraçu, 28.V.1990, Fernandes 2958 (CEPEC, MBML, VIES). Pancas, 30.X.2003, Fraga 1077 (RB).

Esta espécie ocorre nos estados da Bahia, Minas Gerais e Espírito Santo, em afloramentos graníticos da Floresta Estacional Semidecidual (Fig. 1c; Goldenberg et al. 2012). Coletada com flores entre setembro e outubro e com frutos em maio. Merianthera pulchra é similar a $M$. parvifolia mas dela difere pelo maior comprimento do pecíolo e da inflorescência.

5.5. Merianthera verrucosa $\mathrm{R}$. Goldenb., Fraga \& A.P. Fontana, Taxon 61: 1054. 2012.Fig. 4k,1 Árvores ca. 4 m. alt. Ramos não fistulosos, com tricomas glandulares. Folhas opostas com pecíolo 35-45 mm compr.; lâmina 17-25 $\times$ 21-27,5 cm; orbicular, ápice truncado a amplamente emarginado, base peltada, margem inteira, plana, nervuras 5-7, com um par de nervuras submarginais, suprabasais (4-10 mm), face adaxial glabra, face abaxial com tricomas glandulares esparsos. Panículas 6-10 × 10-17 cm compr., apicais. Flores com pedicelos 5-8 mm compr.; hipanto 6-7 ×6,5 mm, nitidamente costado e rugoso; cálice apendiculado, com tubo ausente ou até $0,5 \mathrm{~mm}$ compr., sépalas regulares 2,9-3,7 mm compr.; pétalas 14,3-15,8 $\times 10-11 \mathrm{~mm}$, roxas, obovadas, ápice arredondado a obtuso e levemente cuculado; estames 10, filamentos roxos, achatados, antessépalos com apêndice ascendente rosado, conectivo com apêndice descendente branco, anteras 5,6-6 mm compr., antepétalos com apêndice ereto branco, conectivo com apêndice descendente de cor desconhecida, anteras 6,8-7,6 mm compr.; ovário 5,5-8,6 mm compr., 5-locular, densamente revestido por tricomas glandulares, estilete ca. $15 \mathrm{~mm}$ compr.

Material examinado: São Roque do Canaã, 16.X.2004, Fontana 952 (MBML, HUFU, UPCB); 2.VIII.2011, Fraga 3388 (BHCB, K, MBML, NY, RB, UPCB); 20.V.2015, Goldenberg 2172 (UEC, UPCB, MBML).

Merianthera verrucosa foi coletada apenas no Espírito Santo em afloramentos graníticos rodeados por Floresta Ombrófila Densa (Fig. 1c; Goldenberg et al. 2012). Coletada com flores em agosto e outubro. Esta espécie é similar a $M$. bullata, mas dela difere principalmente desta pela superfície rugosa do hipanto e pelo cálice apendiculado. As folhas com a base peltada são bastante distintas, apesar desta característica não ter sido mencionada na descrição original. 


\section{Agradecimentos}

TB recebe bolsa do CNPq (Doutorado). $\mathrm{RG}$ recebe bolsa do $\mathrm{CNPq}$ (Produtividade em Pesquisa). Parte deste trabalho foi financiada pelo CNPq (Protax 562210/2010-5). Agradecemos ao Instituto Nacional da Mata Atlântica e ao Programa de Capacitação Institucional (MCTI e CNPq), por receber RG em Santa Teresa, ES. Agradecemos a colaboração de Lucas F. Bacci na elaboração das pranchas de fotos e mapas; e a André P. Fontana, Claudio N. de Fraga e Diego Iglesias, o envio e permissão para utilização de suas fotografias.

\section{Referências}

Bacci LF, Amorim AM \& Goldenberg R (2016a) Three new species of Bertolonia (Melastomataceae) from Espírito Santo, Brazil. PeerJ 4: e2822.

Bacci LF, Caddah M \& Goldenberg R (2016b) The genus Miconia (Melastomataceae) no Espírito Santo. Phytotaxa 271: 1-92.

Bacci LF \& Goldenberg R (2015) Miconia valentinensis (Melastomataceae), a new species from Espírito Santo, Brazil. Phytotaxa 195: 272-278.

Baumgratz JFA (2004) Sinopse de Huberia DC. (Melastomataceae: Merianieae). Revista Brasileira de Botânica 27: 545-561.

BFG - The Brazil Flora Group (2015) Growing knowledge: an overview of seed plant diversity in Brazil. Rodriguésia 66: 1085-1113.

Bochorny T, Bacci LF \& Goldenberg R (2017a) Following Glaziou's footsteps: rediscovery and updated description of three species of Behuria Cham. (Melastomataceae) from the Atlantic Forest (Brazil). Phytotaxa 302: 229-240.

Bochorny T, Michelangeli F \& Goldenberg R (2017b) Behuria lumiarensis (Melastomataceae), a new species on a mountaintop of the Brazilian Atlantic Forest. Phytotaxa 305: 111-117.

Fidanza K (2009) Estudos taxonômicos em Cambessedesia (Melastomataceae). Tese de Doutorado. Universidade Estadual de Campinas, São Paulo. 268p.

Fidanza K \& Almeda F (2011) New Species of the Brazilian Endemic Genus Cambessedesia (Melastomataceae). Harvard Papers in Botany 16: 57-63.

Garbin ML, Saiter FZ, Carrijo TT \& Peixoto AL (2017) Breve histórico e classificação da vegetação capixaba. Rodriguésia 68: 1883-1894.

Goldenberg R, Fraga CN, Fontana AP, Nicolas AN \& Michelangeli FA (2012) Taxonomy and phylogeny of Merianthera (Melastomataceae). Taxon 61: 1040-1056.
Goldenberg R \& Tavares RAM (2007) A new species of Dolichoura (Melastomataceae) and broadened circumscription of the genus. Brittonia 59: 226-232.

Goldenberg R \& Reginato M (2006) Sinopse da família Melastomataceae na Estação Biológica de Santa Lúcia (Santa Teresa, Espírito Santo). Boletim do Museu de Biologia Mello Leitão, nova série, 20: 33-58.

Goldenberg R \& Reginato M (2009) New species of Behuria, Miconia, and Ossaea (Melastomataceae) from Eastern Brazil. Journal of the Torrey Botanical Society 136: 293-301.

Goldenberg R \& Kohllmann L (2016) Two new species of Pleroma (Melastomataceae) from Espírito Santo, Brazil. Brittonia 68: 37-45.

Goldenberg R, Michelangeli FA, Aona LYS \& Amorim AM (2016) Angiosperms and the Linnean shortfall: three new species from three lineages of Melastomataceae at one spot at the Atlantic Forest. Peer J. 4: 1824-1833. DOI: $10.7717 /$ peerj.1824

Iglesias DT, Dutra VF \& Goldenberg R (2016) Behuria mestrealvarensis (Melastomataceae): a new species on an inselberg in Espírito Santo, Brazil. Phytotaxa 255: 281-286.

Justino LL, Salinema RFG, Chiavegatto B, Menini Neto L (2016) O clado Merianthera e as tribos Merianieae e Microliceae (Melastomataceae) na Serra Negra, Minas Gerais. Rodriguésia 67: 823-838.

Meirelles J \& Goldenberg R (2012) Melastomataceae do Parque Estadual do Forno Grande, Espírito Santo, Brazil. Rodriguésia 63: 831-855.

Meyer FS, Goldenberg R \& Kohllmann L (2016) Three new species of Pleroma (Melastomataceae) from Inselbergs of Espírito Santo, Brazil. Phytotaxa 282: 197.

Simonelli M \& Fraga CN (2007) Espécies da flora ameaçadas de extinção no estado do Espírito Santo. IPEMA, Vitória. 146p.

Tavares RAM (2005) Revisão taxonômica do gênero Behuria Cham. (Melastomataceae; Merianieae). M.Sc. Thesis. Universidade Federal do Rio de JaneiroMuseu Nacional, Rio de Janeiro. Pp. 209.

Tavares RAM, Baumgratz JFA, Goldenberg R (2008) A new species of Behuria Cham. (Melastomataceae: Merianieae) from Brazil. Botanical Journal of the Linnean Society, 158: 489-492.

Thiers B [continuamente atualizado]. Index Herbariorum: a global directory of public herbaria and associated staff. New York Botanical Garden's Virtual Herbarium. Disponível em $<$ http://sweetgum.nybg.org/science/ $\mathrm{ih} />$. Acesso em 2 abril 2017.

Ziemmer JK, Goldenberg R \& Amano E (2017) Evolution of aquiferous pith and fistulae in Merianthera burlemarxii suggests a rare case of xerophytism in Melastomataceae. Botanical Journal of the Linnean Society $185: 119-127$. 
Lista de exsicatas de Behuria, Cambessedesia, Dolichoura, Huberia e Merianthera do Espírito Santo

Bochorny 134 (2.1), 135 (3.2), 138 (4.1), 143 (1.1). Britto 39 (3.1), 112 (5.1). Chamas 62 (3.1), 69 (4.1). Cielo-Filho 1032 (2.2). Colleta 268 (4.2). Darke D-98 (5.2). Demuner 670 (4.1), 695 (2.1), 824 (3.1), 1064 (4.1), 1071 (4.1), 1191 (5.3), 1258 (3.1), 3858 (1.1), 1653 (1.1), 1783 (3.1), 2153 (3.1), 2250 (5.2), 2579 (5.3), 2587 (4.1), 2598 (5.3), 2925 (5.2), 2967 (5.4), 3266 (4.1), 3285 (4.1), 3289 (4.1), 3997 (5.3), 3298 (5.3), 3498 (4.1), 3844 (4.1), 4009 (5.3), 4233 (5.3). Duarte 3674 (3.1). Esgario 62 (2.1), 88 (5.1), 89 (1.2), 113 (2.1), 154 (1.2), 169 (1.2). Fernandes 1891 (3.1), 2450 (4.1), 2906 (4.1), 2958 (5.4), 3419 (5.4). Flores 1209 (4.2). Folli 1136 (4.2), 2310 (4.2). Fontana 442 (3.1), 518 (4.1), 677 (4.1), 738 (2.1), 824 (2.1), 952 (5.5), 1066 (4.1), 1160 (3.2), 1163 (2.1), 1174 (4.1), 1175 (5.1), 1202 (2.1), 1285 (1.2), 1330 (5.1), 1371 (1.2), 1404 (5.1), 1417 (4.1), 1418 (2.1), 1548 (5.3), 1592 (1.2), 1718 (1.2), 2801 (4.1), 2839 (5.1), 3331 (5.1), 5098 (4.1), 5770 (5.3), 5792 (5.2), 6009 (3.1). Forzza 5747 (5.2), 7528 (2.1), 8757 (4.1). Fraga 966 (4.1), 1077 (5.4), 1088 (5.2), 1161 (1.2), 3388 (5.5). Goldenberg 1141 (5.3), 1153 (5.4) 1154 (5.2) 1258 (4.1) 1448 (4.1) 1518 (1.2) 1627 (2.1) 2216 (4.1). Gomes 3536 (2.1). Hatschbach 54236 (2.2) 69443 (2.2). Hupp 66 (3.1). Hutchison 8472 (5.2). Iglesias 98 (1.3), 169 (1.3), 170 (1.3) (2.1). Kollmann 541 (4.1), 1427 (3.1), 1951 (4.1), 2247 (3.1), 2334 (5.1), 2977 (4.1), 3025 (5.3), 4104 (4.1), 5444 (2.1), 6554 (2.1), 7255 (2.1), 7420 (3.2), 8444 (3.1), 8551 (3.1), 9515 (3.1), 9791 (4.1), 9840 (5.1), 9907 (4.1), 10852 (3.1), 10982 (5.3), 11846 (3.1), 12670 (3.2). Labiak 4029 (3.1). Lima 2981 (4.2). Lombardi 1078 (3.1). Lopes 633 (4.1), 753 (3.1). Lucas 755 (3.1). Luetzelburg 7167 (2.2). Magnago 861 (5.3), 997 (5.1), 1107 (4.1), 1120 (5.3), 1399 (5.3). Mancinelli 1127 (2.2). Mello Barreto 8978 (2.2). Meyer 1479 (2.2), 1492 (2.2). Michelangeli 1569 (2.2), 1598 (5.1), 1599 (2.1), 1611 (3.1). Pereira 2781 (4.2), 3238 (4.2), 3575 (4.2), 5698 (4.2). Pirani 170 (1.3). Pizziolo 279 (3.1). Reginato 1416 (2.2). Saavedra 641 (5.3). Shepherd 5875 (5.2). Silva 237 (4.2). Sobral 8283 (3.1), 14752 (2.2). Varassin 01 (3.1), 18 (3.1). Vervloet 2672 (2.1). Vinha 1166 (1.3), 1177 (2.1). Vimercat 217 (3.1). 